\title{
Justification of The United Nations Organization's CEDAW Charter in Ensuring Women's Rights in Bangladesh
}

\author{
Naznin Huq ${ }^{1 *}$, Md. Rifat-Ur-Rahman ${ }^{2}$ \\ ${ }^{1}$ Assistant Professor, Department of Bangladesh Studies, Stamford University Bangladesh, Dhaka, BANGLADESH \\ ${ }^{2}$ Lecturer, Department of Cultural Heritage and Bangladesh Studies, Rabindra University, Shahzadpur, BANGLADESH \\ * Corresponding Contact: \\ Email: naznin.317@gmail.com
}

Manuscript Received: 18 April 2019 - Revised: 29 June 2019 - $\quad$ Accepted: 16 July 2019

\begin{abstract}
Even with the praiseworthy provisions of the Convention on the Elimination of all forms of Discrimination against Women, (CEDAW) aiming to stop discrimination against women all over the world. Still discrimination of women all over the world is in high range. The situation of Bangladesh in this regard is much worse. The existing stand of Bangladesh regarding Clause 2 and 16-1(c), has made it impossible to fully establish women's right in the country. This paper attempted to make a case for the explanation of fully implementing CEDAW in Bangladesh, using the Constitution of Bangladesh. The Constitution of Bangladesh clearly identifies equal rights for both men and women, whereby non-ratification of two clauses of the CEDAW charter is clearly unjustifiable. Thus this paper has strengthened the case by conducting an extensive literature review of the CEDAW charter along with the state of women's rights in the Constitution of Bangladesh. It will serve as a basis for future changes in policy development regarding the ratification of the CEDAW Charter in Bangladesh.
\end{abstract}

Keywords: Cedaw Charter, Women's Rights, Bangladesh Constitution, Non-Government Organizations

This article is is licensed under a Creative Commons Attribution-NonCommercial 4.0 International License.

Attribution-NonCommercial (CC BY-NC) license lets others remix, tweak, and build upon work non-commercially, and

although the new works must also acknowledge \& be non-commercial.

\section{INTRODUCTION}

Ensuring women's rights in every sphere of the society has nowadays become an important social issue. Although almost one-half of the world population is woman, yet women are subject to serious deprivation both inside and outside their homes. And in this context the condition of the women in Bangladesh is no exception at all. However, ensuring women's rights has been given priority worldwide. Many writers and social activists have been playing significant role in this regard. The core objective of this article is to evaluate the advancement of women's rights and equality in all walks of life in Bangladesh in the light of the CEDAW charter enacted by the UNO, which Bangladesh has ratified too. In addition the article has also attempted to identify the areas in which the 
women still face deprivation, along with a few recommendations through which the country could ensure a level playing field especially for the women so that they can enjoy equality and work without any sort of fear.

\section{Methodology}

This paper is mostly qualitative in nature. Necessary information was collected from various secondary sources such as books, journals, periodicals, and the Internet. Besides, few data has been collected through informal yet in-depth discussions with academicians, NGO people, and grass root level women regarding this issue in order to ensure the validity and reliability of the data and information of secondary sources. However, in combination of primary and secondary data it helps to develop comparative analysis and justification of CEDAW Charter in Bangladesh. Finally, this paper will attempt to draw some recommendations for the policy planners.

\section{BACKGROUND OF WOMEN RIGHTS}

The UNO has been playing a pivotal role in increasing awareness about the rights of women vis-à-vis improving their conditions across the world. The issue of women's equal rights has got special priority in the UN Charters and the Universal Human Rights Declaration. In protest against 12 hours' work per day, lower wages, and assault, the women workers of the needle factory of New York outburst on $8^{\text {th }}$ March 1857. Afterwards in an international conference of the communist-minded women at Copenhagen in the year 1910, it was proposed to declare $8^{\text {th }}$ March as Women's Day, and accordingly in 1974 the UNO had declared the day as the International Women's Day.

In a bid to remove all sorts of deprivation against women the UNO in 1979 had undertaken the historic "Convention on Elimination of All Forms of Discrimination against Women (CEDAW)" and it came into effect in the year 1981. This is considered as an international bill of rights for women. More than 160 countries had given consent to ratify this charter. In order to draw concentration to women's rights the UNO had declared 1975 as the Women's Year and 1975-1985 as the Women's Decade. While celebrating the first Women's Year the UNO had organized the first ever Global Women's Conference. Afterwards the same sort of conferences took place at Copenhagen in 1980, at Nairobi in 1985, and at Beijing in 1995. It is noteworthy that two sister concerns of the UNO have been working solely for women. The UNIFEM has been funding especially the rural women from the developing countries for new types of development initiatives.

\section{What is CEDAW Charter?}

CEDAW stands for the Convention on the Elimination of all forms of Discrimination against Women which adopted on December 18, 1979 by the United Nations. It is also known as the "Women's Convention" or the "Women's Bill of Rights". The Convention is the most comprehensive and detailed international agreement, which seeks the advancement of women. It establishes rights for women in areas not previously subject to international standards. The Convention entered into force as an International Treaty on September 3, 1981. The Convention as of May 31, 2002, has 168 member states.

The Convention provides a universal definition of discrimination against women and sets up an agenda for national action to eliminate such discrimination. It defines discrimination against women as, "... any distinction, exclusion or restriction made on the basis of sex which has the effect or purpose of impairing or nullifying the recognition, enjoyment or 
exercise by women, irrespective of their marital status, on a basis of equality of men and women, of human rights and fundamental freedoms in the political, economic, social, cultural, civil or any other field." The Convention also calls for actions in nearly every field of human endeavor: politics, law, employment, education, health care, commercial transactions and domestic relations. Moreover, it establishes a Committee to review periodically the progress being made by its adherents.

CEDAW consists of a preamble and 30 articles and it can be divided into following three broad categories:

1. Article 1 to Article 16: ensuring equality between men and women.

2. Article 17 to Article 22: UN CEDAW Committee and its mandate.

3. Article 23 to Article 30: administration of the treaty.

By accepting the Convention, concerned State parties commit themselves to undertake a series of measures, including legislation and temporary measures, to end discrimination against women in all forms. States parties should ensure in every sphere of life, that women enjoy all the human rights and fundamental freedoms. Countries that have ratified or acceded to the Convention are legally bound to put its provisions into practice. They are also committed to submit national reports, at least every four years, on measures they have taken to comply with their treaty obligations. It may be mentioned that the Convention permits ratification subject to reservations, provided that the reservations are not incompatible with the object and purpose of the Convention.

Recently, on December 22, 2000 the Optional Protocol to the CEDAW Convention entered into force. States which ratify the Optional Protocol recognize the competence of the CEDAW Committee - (a) to consider petitions from individual woman or groups of women who have exhausted all national remedies through a 'communication procedure'; and (b) to conduct inquiries into grave or systematic violations of the CEDAW Convention through an 'inquiry procedure' (Afroz, 2012).

\section{Women Rights in Bangladesh}

The Constitution of the People's Republic of Bangladesh ensures the equality of every citizen and that no discrimination could be done between men and women. Although Article 28(4) asserts formulation of special laws particularly favoring children and women, women's rights of equality is not is not being properly ensured in Bangladesh. Despite the fact that the Government of Bangladesh had ratified in 1984 the Charter declared by the UNO in the year 1979, the government has kept reservation of Section (2) and 16-1 (c) of the Charter which-according to the experts-act as a significant barrier to ensuring equal rights for women in our country.

The Government of Bangladesh ratified the CEDAW on November 6, 1984. However, at the time of ratification, the Government of Bangladesh made reservations to a number of provisions of the Convention. These included:

a. Article 2: policy measures.

b. Article 13(a): equality as to the right to family benefits.

c. Article 16(1)(c) : equal rights and responsibilities during marriage and at its dissolution.

d. Article 16(1)(f) : equal rights and responsibilities with regard to guardianship,

wardship, trusteeship and adoption of children etc. 
The Government of Bangladesh has put forward the following reasons for such reservations:

a) Bangladesh is a Muslim populated country. The prevalent Muslim Personal Laws are essentially based upon Shariah Laws, which in turn were formulated in light of the Holy Quran and Sunnah. Therefore, the provisions of personal law could not be changed as easily as required by the Convention as they were based on religion.

Likewise, after many changes, inclusion, and exclusion the Government of Bangladesh has declared the Guidelines for Women's development. Ironically women's equal rights both in and outside the family still remains a far cry. According to Muhammad (1997), "in order to ensure equal rights for women in truest sense requires highly rigid and strong laws and their implementation, in addition to ensure changes in the attitude of especially the male citizens of the country."

The "Women's Decade of the UNO" has acted as the catalyst for organizing women to ensure the issue of women' equality in our country. So far, Bangladesh has taken part in few conferences of the UNO. The following ones are noteworthy:

\begin{tabular}{|c|l|}
\hline Year & \multicolumn{1}{|c|}{ Event } \\
\hline 1975 & The International Women's Year 0f 1975 \\
\hline 1980 & $\begin{array}{l}\text { Participated in the International Women's Conference at Copenhagen in 1980 } \\
\text { and signed the conference declaration }\end{array}$ \\
\hline 1984 & $\begin{array}{l}\text { Ratified the CEDAW in November 1984 excepting a few clauses, which } \\
\text { according to the then government, were conflicting with the country's } \\
\text { Constitution }\end{array}$ \\
\hline 1985 & $\begin{array}{l}\text { Participated in the last conference of the Women's Decade and the National } \\
\text { forward looking strategy (1985) }\end{array}$ \\
\hline 1991 & Formulated Women in Development in the year 1991 \\
\hline 2004 & $\begin{array}{l}\text { Participated in the 4 } 4^{\text {th }} \text { International Women's Conference at Beijing in 1995 } \\
\text { and ratified the recommendations for women's development }\end{array}$ \\
\hline 2010 & actively participated in the Beijing+5 as well as Beijing+10 conferences \\
\hline
\end{tabular}

Soon after independence Bangladesh had made ties with various international forums, especially with the UNO regarding different programs focusing the socio-economic development of the women. Apart from the programs undertaken by the international communities, the then Government of Bangladesh had also implemented various programs to improve the conditions of the women. But none of these programs have produced the desired result.

The Constitution has necessitated the enactment of special law (if necessary) for bringing the women forward. The rights of the women that are mentioned in Bangladesh's Constitution are mentioned below:

\begin{tabular}{|l|l|}
\hline (Principles of State Mechanism-9) & $\begin{array}{l}\text { the State shall encourage the participation and } \\
\text { representation of farmers, labors, and women in the } \\
\text { local level government }\end{array}$ \\
\hline (Principles of State Mechanism-9) & $\begin{array}{l}\text { Participation of women at every sphere of national } \\
\text { life shall be ensured }\end{array}$ \\
\hline (Article 28(4)). & $\begin{array}{l}\text { Special Act can be enacted for the progress of children, } \\
\text { women, or any backward section of the citizens }\end{array}$ \\
\hline
\end{tabular}


However, starting from the Constitution to the various programs that had been undertaken for improving the women's condition along with the barriers that had affected the implementation of those programs have been discussed underneath so as to detect the standing of Bangladesh in safeguarding women's rights.

In addition to the aforesaid points equality of male and female has been emphasized in quite a few parts of country's constitution. According to Justice Debesh Chandra Bhattachariya, "... the above like directives or declarations could not free the long-existing social practices from the liability of the new process. The previous discriminations have still being prevailing even after the days of the enactment of the Constitution. Due to the absence of effective mechanism of implementing the fundamental rights given to the women along with the absence of conducive socio-economic environment the entire women still remain an underprivileged section of the entire population. It is become difficult for the women to participate in the social welfare activities. But, notwithstanding this, it is true that the fundamental rights mentioned in the Constitution and the basic principles of State mechanism along with other Clauses have paved the way for the development of women in the country" (Akter, 1995).

Within a couple of years of our Independence in 1975, Bangladesh undertook the programs of the UNO-declared World Women's Year. In this backdrop the General Assembly of the UNO has enacted CEDAW, which is considered as a milestone towards achieving the equal rights for the women. In the fourth World Women Conference in 1995 in order to ensure women empowerment and progress a wider plan of action was undertaken. In that plan of action by identifying all the barriers for attaining women's progress and equality, strategy and programs in the form of Platform for Action (PFA) to overcome was undertaken. As the global framework for principles of women's development, Bangladesh has also fully ratified the PFA. Later on in 1997 Bangladesh has enacted the National Policy for Women's development. However, an evaluation of the programs and policies undertaken so far by the Government of Bangladesh for implementing Beijing Platform for Action and the CEDAW charter makes this clearer.

\section{The CEDAW Charter and Bangladesh}

Bangladesh ratified the CEDAW Charter on $6^{\text {th }}$ November 1984. This means that the Government of Bangladesh is committed to undertake all sorts of necessary actions required to implement the CEDAW Charter. To this end, though, it is to be noted that by tendering objection against two clauses of the CEDAW Charter viz. Clause \# 2 and 16-1 (c) Bangladesh did not ratify them. Non-ratification of these two important clauses of the CEDAW Charter has been considered as the main obstacle towards complete implementation of the CEDAW Charter in Bangladesh.

As to why the Government of Bangladesh did not ratify the particular clauses/sub-clauses of the CEDAW Charter, the Government had argued that being a Muslim-majority state, Bangladesh Government cannot ratify any sort of policy or program which has the potential to conflict with Muslim or Shariah laws. Equality for women in every sphere of life has been clearly mentioned in the Constitution of Bangladesh. Getting complete constitutional honor was actually one kind of endorsement of the proud role that the women had played during the country's Liberation war. Articles 10, 18, 27, 28 and 29 have categorically demarcated the domains of the rights of both male and women. These clauses have also ensured equal treatment for both male and female citizens of the 
country. It is, therefore, that non-ratification or partial ratification of the CEDAW charter means violation of men and women's constitutional equality. The core philosophy as well as goals and objectives of the CEDAW charter are to eradicate all sorts of discriminations facing women. To this end, it can be argued that, imposing reservation or restriction of any sort contradicts with the core philosophy of the CEDAW charter, and it also reflects the disinterest of the Government of Bangladesh to completely implementing the CEDAW Charter.

The strongest aspect of the CEDAW charter is that instead of ensuring women's rights in black and white, it had put especial emphasis on uprooting the elements that propels discrimination of women. Indeed, it really does not make any sense of imposing any reservation or restriction especially after ratifying the Beijing Declaration of 1995 as well as the Beijing Platform for Action. True to say, since Bangladesh had already been one of the signatories of almost all the declarations, international charters and conventions regarding, keeping reservation on the two clauses of the CEDAW Charter has automatically become null and void (Steps Towards Development: 2001).

Countries such as Mexico, Sweden, and the Netherlands-to name a few-had protest against Bangladesh's restriction of the two clauses. In 1996 the Ministry of Women and Children Affairs of the Government of Bangladesh had formed a Review Committee with a view to assess the validity of the reservations imposed by Bangladesh. According to that Committee, "since Bangladesh did not impose any reservation in the Child Rights Charter, hence, there is no logic or reason of imposing reservation on the Clauses 2 and 16.1(c) of the CEDAW Charter. Moreover, since Bangladesh did not also impose any reservation in the Plan for Action mentioned in the Beijing Declaration in which the similar kind(s) of women's rights." On the basis of these points the Review Committee had recommended to withdraw the restrictions (Begum, 2008).

\section{Does the Constitution of Bangladesh Conflicts with the CEDAW Charter?}

An interesting finding comes out from a comparative analysis of CEDAW clauses and the concerned articles and sections of our Constitution. The Constitution of Bangladesh strictly prohibited any sort of discrimination between male and female citizens of the Republic. In addition, all types of laws and rules that have the potentiality of contradicting with the women's constitutional rights and legal framework have been declared to be null and void. CEDAW's non-discriminatory policy for women is to a great extent similar to various clauses of Bangladesh's Constitution; this similarity might play pivotal role for Bangladesh to implement the CEDAW Charter.

In the same time, noticeable commonalities between our Constitution and the CEDAW in terms of other laws, policies etc. articulated for the progress and empowerment of the women, two basic necessities-which are considered as the precondition for establishing gender-equality-were not incorporated in our Constitution:

First: the Constitution did not declare 'gender discrimination' as neither illegal nor unacceptable; and

Second: equality of men and women at the family and personal level was not addressed.

Due to the absence of these two issues in the Constitution it has not been possible to implement the CEDAW Charter entirety, despite of the assurance of equality of all citizens, women of our country. 


\section{Contribution of the NGOS in Implementing the CEDAW Charter's Clauses}

Whereas the CADEW has been a strong instrument of establishing women's rights, an effective mechanism of observing and evaluating the activities of the countries committed to implement the CEDAW Charter is "shadow report." Prepared by private organizations or NGOs, the shadow Report is a supplementary analytical report of the CEDAW-related national report prepared by the countries which had ratified the CEDAW Charter. The organizations which prepare the Shadow Report in Bangladesh include the Association of Development Agencies of Bangladesh (ADAB), CEDAW Forum, Bangladesh Mohila Parishad, and Naripokkho.

The eighth clause of the CEDAW Charter deals with the representation by the women at the international level. But unfortunately extremely meager number of initiatives has been undertaken by the Government to send women as member of delegates outside the country i.e. international forums. Two issues are important in implementing government's commitment.

First: to ensure equal treatment in opportunities and privileges as well as the spheres of increasing skills and experiences required of representing the country at the international level.

Secondly, to ensure wide circulation of the availability of such opportunities to a wide range of audiences as well as selecting the delegate members through a transparent process free of corruption, nepotism, and favoritism.

The delegate members of the non-government organizations in the CEDAW meeting had given special emphasis on the issues noted underneath:

- Bangladesh Government has still kept reservation on the $2^{\text {nd }}$ Clause, which acts as an impediment in ensuring gender equality as well as removing discrimination;

- The women have got no right to making decisions on whether or not to go under safe custody;

- Discriminatory citizenship law still exists, which clearly contradicts with the $9^{\text {th }}$ Clause of CEDAW;

- The non-resident Bangladeshi women working abroad have got no job guarantee;

- Government initiatives to stop domestic violence are by no means sufficient;

- No specific steps have been undertaken for monetary and job security for the RMG workers after the phase-out of MFA;

- No affirmative step has been undertaken to ensure effective and active participation of the women in national politics;

- No meaningful initiative has been taken in order to strengthen the institutional mechanisms to stop discrimination against women; and

- No visible initiative has been undertaken to materialize the clauses of the CEDAW Charter which Bangladesh have ratified.

\section{CONCLUSION}

From the above discussion it has become clear that despite a lot of urgency in implementing the CEDAW Charter in Bangladesh by various stakeholders, the Governments have not shown serious eagerness and sincerity regarding establishment of women's rights. Ironically, although different governments have enacted different legal frameworks in order to cope with the international community, due to non-implementation of those laws, rules, and regulations along with due to unawareness about the benefits and necessities of women's rights among the common masses, establishment of women's rights in Bangladesh still remains a far cry. And as 
a result of this overall development of the country is yet to be satisfactory even after more than forty years of Bangladesh's Independence.

To ensure the gigantic task of establishing women's rights cannot be done by the government or by the civil society and the NGOs alone. Instead it requires a wellconcerted effort of the trio of government, civil society, and NGOs. In this case the task of coordination has to be done directly by the government. The sooner the Government of Bangladesh realizes this very truth, the better would be the chance for the country to reach its goals articulated in the Constitution of Bangladesh.

However, on the basis of the above discussion it can be noted that in order to completely ratify the CEDAW Charter to ensure women's rights in Bangladesh could be followed some recommendation. The success that Bangladesh has gained in education, employment, and micro-credit should be continued. Bangladesh's Constitution and laws do not ratify the CEDAW Charter in its entirety. Significant number of barriers still exists in the process of implementing the CEDAW Charter. Discrimination has no unique definition. People of the Judiciary, health, and other law-related people require rigorous, practical and realistic training. Presence of people from women's organization and NGOs are praiseworthy, but the real onus lies with the government. To stop violence against women more vast and effective awareness and motivational programs need to be undertaken. Only giving capital punishment is not sufficient, social tradition and culture etc. need to be changed; and restriction on the two clauses imposed by the Bangladesh Government must be withdrawn.

For the $2^{\text {nd }}$ clause, in line with the pledge given in the $3^{\text {rd }}$ and $4^{\text {th }}$ Periodic report all sorts of restrictions and bars is withdrawn without any further delay. After the removal of the restrictions necessary steps must be taken in order to the CEDAW-proposed clauses are to be incorporated in the family law. For the $5^{\text {th }}$ clause, necessary, down-to-earth law should be enacted vis-à-vis most specific steps be taken. For the $7^{\text {th }}$ clause, election law be changed for direct election in the female constituency. In conclusion, it can be anticipated that women's rights in Bangladesh would soon be ensured if the above recommendations are taken into consideration by the parties concerned with the CEDAW Charter.

\section{REFERENCES}

Afroz, B. T., 2012. CEDAW and the Women"s Rights in Bangladesh - a promised Silver Lining.

Akter, T. 1995. Mohila Unnoyon o Porikolpona: Bangladesh Prekkhapot. Dhaka: Bangla Academy. pp. 63-64.

Begum, H. 2008. CEDAW and Bangladesh. Dhaka: Bagladesh Orthonity Shamity.

Begum, M. 1993. Gram Shalish Kotota Nay Bichar Dey? Dhaka: Ononnya.

Islam, M. 1998. Nari: Etihas Upekkhita. Dhaka: Maowla Brothers. pp. 117-18.

Khan, S. 2003. Antorjatik Manobadhikar Ain o Narir Shamota. Dhaka: Women for Women.

Mannan, A., and Khanom, S. 2006. Nari o Rajniti. Dhaka: Oboshor Prokashoni.

Muhammad, A. 1997. Nari, Purush o Shomaj. Dhaka: Shondesh.

Rahman, G. S. 1990. Nari Proshonge Bangladesher Ainer Bhashyo. Dhaka: ASA.

Steps towards Development (STD). 2001. CEDAW o Bangladesh, Shongbidhan Ain O Jatiya Uddog: Ekti Tulonamulok Shomikkhya. Dhaka: STD.

Steps towards Development (STD). 2007. CEDAW and women rights. Dhaka: STD. 